\title{
Kockázatvállalás \\ ÉS KÍSÉRLETEZÉS, AVAGY MIRŐL SZÓL AZ INKLÚZIÓ?
}

\author{
KARDOS DOROTTYA \\ ELTE PPK Neveléstudományi Doktori Program
}

Chris Forlin \& Tim Loreman (eds): Measuring inclusive education. (International perspectives on inclusive education. Volume 3.) Bingley, 2014. Emerald. xvi +312 p. ISBN: 978-1-78441-146-6

A nemzetközi oktatáskutatás aktuális témája az inkluzív feltételek megteremtési lehetőségei és az oktatási intézmények befogadó közösséggé formálásának útja. $\mathrm{A} z$ inkluzív oktatás mérése igen bonyolult, mivel a rendszer maga is többtényezős, komplex. Könnyebb mérni, hogy hány gyermek vesz részt az oktatásban, milyen a fiúk, lányok aránya, hányan teljesítik sikeresen a tanévet, vagy hányan kapnak SNI (speciális nevelési igény) státuszt. Mi azonban az inklúzió? Miért tekintjük mindenki érdekének? Hogyan és miért szükséges mérni? Ezekre és még sok hasonló kérdésre keresi a választ a bemutatott kötet, mely harmadik kiadás, témáját tekintve inkluzív oktatási törekvéseket és azok hatékonyságának mérési lehetőségeit, modelljeit állítja középpontba. A témaválasztás fontosságát két indokkal támasztja alá. Először is megnövekedett $a z$ igény az intézmények részéről, hogy pontos és megbízható mérési eszközökkel kapjanak képet hatékonyságukról, erősségeikről, fejlesztendő területeikről. A második érv szorosan kapcsolódik az elsőhöz és az eredmények szakszerű felhasználására hívja fel az olvasó figyelmét, mivel a pontos és igényalapú oktatási célok kitüzéséhez szükséges felmérni az aktuális gyakorlatokat.
$\mathrm{A} z$ inkluzív oktatás bemutatása során a szerzők a modern fogyatékosügyi nézetek mentén gondolkodnak a speciális szükségletű tanulókról, eltávolodva a deficitalapú modelltől. A diverzitást értéknek tekintik, az inkluzív oktatást pedig folyamatként értelmezik, aminek alapja az egyes tanulók speciális igényeinek felmérése és kielégítése. Az angol nyelvű kötet két nagy részre oszlik, az első rész egy elméleti bevezető, amely alapot nyújt az inkluzív oktatás, az etikai dilemmák megértéséhez. A második rész rendszerszinten foglalkozik a befogadó iskolák és a tanári kompetencia mérési lehetőségeivel, illetve stratégiákat és modelleket tárgyal a gyakorlat oldaláról.

A kötet első fejezete ( $A z$ inkluziv oktatás mérésének kérdései) kísérletet tesz az inkluzív oktatás definiálására, illetve annak bemutatására, hogy az mennyire tágan értelmezett fogalom. A legtöbb fejezet saját definíciót és tartalmi keretet ad az inklúzióról, így a kötet gazdag elméleti szempontból, de ez a definíciós sokszínüség azt is mutatja, mennyire nincs egységes fogalmi rendszere a területnek. A befogadó oktatás implementálását nehezítő tényezők is feltűnnek, a lista pedig szerepelteti az idő- és támogatásbeli nehézségeket, a magas létszámú osztályok helyzetét, a tanári előképzettség hiányát. 
A pedagógusokra hárul a felelősség, hogy a fogyatékossággal élő tanulókat inkluzív osztályokban oktassák, gyakran gyógypedagógiai vagy pedagógiai asszisztensi segítség nélkül. A tanárképzés során sem kapnak megfelelő felkészítést az egyre heterogénebb tanulócsoportok differenciált oktatására. Copfer és Specht fejezetükben (1. rész 6. fejezet) felteszik a kérdést, bogyan lehet megfelelöen felkésziteni a pedagógusokat arra, bogy sikeresen oktassák az összes tanulót? A válasz igen sokrétü, tartalmazza az elméleti tudásátadást a különböző fogyatékossági típusokról, a szemléletformálást és érzékenyítést, a továbbképzések biztosítását és a tanári kollaboráció elősegítését.

Agnes Gajewski (1. rész 2. fejezet) tanári perspektívából vizsgálja a különböző etikai dilemmákat. Interjúk segítségével a gyakorlat aktuális és igazi nehézségeit tárja fel, nem elhallgatva a részleteket. Azok a tanárok, akik pályájuk során korábban leginkább tipikusan fejlődő gyerekeket tanítottak, általában semmilyen felkészítést nem kaptak SNI-s gyerekek fogadására, és gyakran nem kérdezi őket senki az ő szükségleteikről. A frusztráció és a többletfeladatok miatt elsőre nem látják a gyermek oldalát, azt, hogy a fogyatékossággal élő gyermek és az osztálytársai mennyit tanulhatnak az inkluzív osztálykörnyezetből. Mit tehet a gyógypedagógus, amikor például azt hallja a tanároktól, hogy „az ilyen gyerekek", teszi fel a kérdést az egyik interjúalany. Számos etikai dilemma merül fel a fejezetben, amelyek jól mutatják a gyógypedagógia nehézségeit ( $\mathrm{pl}$. amikor a gyógypedagógus kiáll a fogyatékossággal élő gyermek jogaiért, de közben veszélyezteti kollegiális kapcsolatait, így a jövőbeli együttmüködést).

A diagnosztizálás fejlődésével és az ahhoz való hozzáférés szélesedével egyre több gyermek kapja meg az SNI-státuszt, így többen részesülhetnek a megfelelő fejlesztésben. Ezzel együtt az iskolák finanszírozási szükségletei is megnövekedtek, írja Donna Barrett (1. rész 5. fejezet). Ezáltal szükség van a tanárok képzésére, rugalmasságra a tanítás során és az ehhez szükséges eszközök biztosítására. A fejezet kiemelten aktuális témája a minőségi iskolai vezetés szerepe az inkluzív szemléletü iskolákban. Napjainkban egyre több kutatás helyezi a hangsúlyt az inkluzív vezetésre, az inkluzív vezetői magatartásra. A tanárok és az iskola egésze csak megfelelő vezetéssel képesek olyan befogadó iskolát kialakítani, ahol szorgalmazzák a tanárok közötti kollaborációt, elősegítik a differenciált oktatást, és a kérések meghallgatásra találnak. A fejezet egyik megfontolandó ajánlása, hogy a tanári értekezlet adjon teret belső képzésre és intervenciós programok kialakítására.

A vezetésről szól az Agbenyega és Sharma által írt fejezet is (1. rész 1. fejezet), amelyben a szerzők azt hangsúlyozzák, hogy az iskolai vezetésnek proaktívnak, innovatívnak kell lennie, amikor inkluzív oktatásról van szó, és fel kell mérniük erősségeiket és fejlesztendő területeiket, illetve kockázatot vállalva új tanítási módszerek kipróbálására kell törekedniük. Ezt a fajta szakmai kísérletezést és kockázatvállalást az iskolai vezetésnek támogatnia és egyben szorgalmaznia is kell, egy olyan intézményi atmoszférát kialakítva, ahol megengedett új dolgokat kipróbálni az inklúzió elősegítése érdekében.

Mivel ez egy komplex és folyton változó rendszer, így a mérésére sem lehet egyszerü eszközöket alkalmazni. Az első rész utolsó fejezete nemcsak strukturális, hanem tartalmi átvezetőként is szolgál, előkészíti a második rész mérésorientált fejezeteit. Egy hét elemből álló megfigyelési skála segítségével mérték fel a tanári hatékonyságot inkluzív szempontból. A skála használható olyan pedagógusok által is, akik szeretnék saját hatékonyságukat 
és fejlődésüket mérni, illetve a szakértők munkáját is támogatja.

A második rész első fejezete az európai inkluzív oktatás mérési lehetőségeit mikro-, mezo- és makroszinten vizsgálva nyitja meg a mérésről szóló fejezetek sorát. Mikroszinten az egyes tanulókkal, pedagógusokkal foglalkozik, tulajdonképpen az osztálytermi valóságot vizsgálja az intézményekben. Mezoszinten az iskolákat és azok müködését kutatja, a makroszint még tágabb, és azokat a rendszereket né$z i$, amelyekben az intézmény müködik. Kiemeli, hogy a komplexen müködő rendszereket, mint az inkluzív oktatás, többtényezős mérési eszközökkel lehet eredményesen felmérni, így Loreman, Forlin és Sharma a gyakorlat, a szakpolitika és a tanulói oldal megismerésére és összehasonlítására hívja fel a figyelmet.

A több fejezetben említett Booth és Ainscow-féle, világszerte alkalmazott inklúziós index kapja a főszerepet a második rész második fejezetében. A fogyatékossággal élő gyermekek integrált oktatása többről szól, mint fizikai jelenlétről az osztályban, magában foglalja teljes bevonásukat a tanulmányi és szociális tevékenységekbe, ami azt jelenti, hogy az iskola egész működése és légköre befogadó kell legyen. Carrington és Duke Ausztráliában végzett kutatást, az inklúziós indexet módosításokkal felhasználva, mivel a nyelvezet és a kérdések adaptálásra szorultak, hogy azok illeszkedjenek az ausztrál kontextusba. Másoknak is ajánlják az indexet, amely kedvezően hathat egy diskurzus elindítására az aktuális helyzetről, a fejlesztési lehetőségekről.

A következő fejezet a regionális hálózatok fontosságát tárgyalja a csendes-óceáni térségben, amely egy kifejezetten sokszínü és tagolt terület etnikai és egyben nyelvi szempontból. A több száz szigetből álló területen 1000 különböző nyelven beszélnek, így a networking önmagában kihívást jelentő feladat. Ebben a szétszabdalt térségben fontosnak tartották, hogy az inkluzív oktatás fejlesztése érdekében kollaboráció szülessen: olyan rugalmas networking rendszerre törekedtek, amely az izolált működés ellen veszi fel a harcot.

Egy írországi felsőoktatási intézmény (University of Aberdeen) esetét mutatja be Spratt és Florian (2. rész 6. fejezet), ahol egy inkluzív oktatásra felkészítő kurzust tartottak a tanárképzős hallgatóknak, illetve az mesterképzési formában is elvégezhető a már pályán lévő pedagógusok számára. A három alapelv, melyre építettek, tulajdonképpen a teljes kötet hitvallása is: 1. a tanulói diverzitás elfogadása; 2. az a szemlélet, hogy minden pedagógus képes minden tanulót oktatni és 3. az ehhez szükséges a kooperáció a szakemberek között. A fejezet tanárszakos hallgatókkal és már tanító pedagógusokkal készített interjúrészleteken keresztül mutatja be, hogyan implementálták a kurzust végzettek a tanultakat. Az egyik ismertetett példában két pedagógus müködött szorosan együtt annak érdekében, hogy megfelelő segítséget nyújtsanak a tanórán az angolul nem beszélő tanulóknak (ahelyett, hogy mindig elküldték volna fejlesztésre). Egy másik pedagógus pedig a fogyatékossággal élő gyermekek osztályának közös játékdélutánt szervezett egy közeli általános iskola tipikusan fejlődő tanulóival. Ilyen és még sok remek, inspiráló projektről olvashatunk, belölük akár ihletet meríthetünk - elköteleződésen kívül tulajdonképpen nem kell sok a megvalósításukhoz.

A kötet záró fejezete Georgia államban (USA) vizsgálta 2003 és 2007 között több mint 67000 enyhe fogyatékosságban érintett, integrációban tanuló gyermek végzettségszerzési arányait. Az eredmények bemutatták, hogy a fogyatékossággal élő tanulók alacsonyabb arányban szereznek végzettséget, mint tipikusan fejlődő társaik. Habár törvényileg szabályozva van 
a fogyatékossággal élő tanulók egyéni tanulási útjának támogatása, a gyakorlatban ez mégsem mindenhol valósul meg, illetve gyakran kevesebb lehetőséghez férnek hozzá vagy nem az igényeikhez vannak szabva. Felmerül a kérdés, lehet-e egy mindenki számára megfelelő kurrikulumot kidolgozni? A válasz nem egyszerü, mivel a fogyatékossággal élő tanulók számára ez nem lenne ideális, de még a tipikusan fejlődő tanulók sem illenek bele egy standardizált, rugalmatlan kurrikulumba. Bár az iskolát elvégző tanulók száma valamennyire tükrözi az adott intézmény sikerességét, az inklúzió vizsgálatának szempontjából ezek csupán számok. Szükség van mélyebb megértésre és a szükségletek felmérésére. A kötetnek ezzel a fejezettel hirtelen van vége, nincsenek összegző, záró gondolatok.

Összességében elmondható, hogy a kötet gazdag értelmezések és mérési lehetőségek bemutatása terén, illetve modern szemléletben vizsgálja a fogyatékossággal élő tanulók helyzetét, mely nagyrészben tükröződik a szakszóhasználatban is, de feltűnnek kifejezések, melyek ma már nem állják meg a helyüket, mint például a regular (szabályos/szokványos) tanuló, amely helyett elfogadottabb a „tipikusan fejlődő" tanuló elnevezés.

A cikk a Creative Commons Attribution 4.0 International License (https://creativecommons.org/licenses/ by-nc/4.0/) feltételei szerint publikált Open Access közlemény, melynek szellemében a cikk bármilyen médiumban szabadon felhasználható, megosztható és újraközölhető, feltéve, hogy az eredeti szerző és a közlés helye, illetve a CC License linkje és az esetlegesen végrehajtott módosítások feltüntetésre kerülnek. 